\title{
Jobtifetime Steering the course for the SUNY Maritime College Library
}

If you're the kind of librarian who will never be too busy or too important to stop and help a student, then directing the library for the Maritime College of the State University of New York (SUNY) may be your job of a lifetime. Constantia Constantinou has been library director and department head since 2001.

\section{Bringing the library to the students}

As you walk into the main hall of the Stephen B. Luce Library, you may notice a student waving up at a big window that overlooks the entire library. They are actually waving at the li-

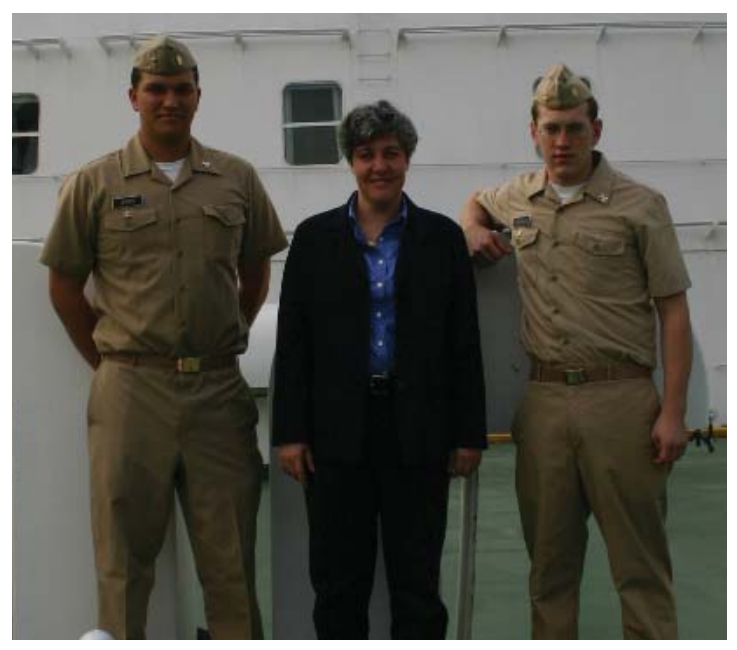

Constantia Constantinou on the Fore Deck of the Training Ship Empire State VI with two SUNY Maritime College Cadets.

brary's director, who is on a first-name basis with many of the 1,300 cadets who make up the student population. How is such familiarity possible for a busy director?

"I have a routine in the morning when I come in," describes Constantinou. "We have a little café, so students stop at the library to fortify themselves with coffee before they go off to their classes. I make my walk around the library and talk with the students. You'd be surprised how willing they are to express themselves. This week and next they're studying for their coast guard license exams, so they're very excited about that. I pull up a chair and sit with them, and we chat a little bit. The last thing I always say to them before I walk away is, 'Make sure you know where my office is.' They absolutely do come and ask questions."

Constantinou is passionate about bringing the library to the students. "To be successful you have to be very student-oriented, you have to be part of the students' everyday life. The librarians serve as freshmen student advisors. We assist them during the registration period in choosing the right courses for their majors, and this gives us the opportunity to bond with them. We get to see all freshmen through our information literacy courses, and we continue to reinforce our relationship with them through the courses where we participate in teaching.

"It helps that they live on campus and that we are in such close proximity throughout the day. We sit and have lunch, participate in campus-wide activities-like faculty-student

Danianne Mizzy is assistant head of the Engineering Library at the University of Pennsylvania. Have an idea for a "Job of a Lifetime" story? E-mail: danianne@seas.upenn.edu 
softball games-serve on student-faculty committees, and even [serve] as the advisors for student clubs. Our goal is to be a part of their ambitions and their aspirations, to be there as a mentor and a teacher as well as a librarian.

"We march with them every May at graduation, and it's sad to see them go. On the other hand, this is why we're here-to help them graduate and to see them become successful leaders."

\section{Anchors aweigh}

Another way the librarians get to know the students so well is by spending the summer term at sea aboard the 565-foot Empire State VI training ship. "The cruise lasts about nine weeks during which they visit at least five ports, two domestic and three European. The shipboard community consists of about 600 to 700 students, 100 faculty and staff, and a librarian (in uniform) serving as their information specialist. Besides helping the students with reference questions and supporting the courses, the librarian is responsible for preparing lectures for the students pertaining to each port of call. These cover social etiquette, customs, places to see, and the librarians even arrange trips. This expands the role of the librarian from academics to an all-around information specialist. Being with them for two months at sea in a very confined space, sleeping and eating in the same environment, we can't help but become a part of their lives."

Constantinou observed that "It requires physical and mental discipline to do such an assignment. You wonder, 'How am I going to manage at sea for two months without my family or my TV or my cell phone?' But if we allow ourselves to remain in tune with our students and share their excitement and enthusiasm, that's when we become adven-

turous ourselves. I have seen my librarians come back different people, more confident, more adventurous, and more fit than when they left." In December, Constantinou will be off on her own adventure, a two-month leave working on a project at the University of Cyprus Libraries as the recipient of a Fulbright Senior Specialist grant (for more information, see www.cies.org/specialists).

\section{Not what you find on a job description} Constantinou characterized her job as "Not the type of librarianship you find on a job description. As a director you have your set duties, but it's what you continue to reinvent and what you create on a daily basis. You get inspired by the students, you get inspired by the faculty, and by the innova-

\section{director}

What: Stephen B. Luce Library

Where: Maritime College of the SUNY

For more information, visit:

www.sunymaritime.edu/zpt/z02/z0200. makka?z=903 tions that happen on campus.

"Then you always think, 'How could the library contribute to this initiative? What will be the library's role in making this project successful? Is this a new opportunity for this library to extend itself?'

"For example, last semester the faculty voted for a new maritime history/maritime museum studies program in the humanities. I said, 'Why not maritime library studies, too, so that students who choose to major in maritime history might become the future directors of maritime museums or libraries."

\section{The adventure of a lifetime and a lifetime of adventure}

When I asked what the key to being successful at this job was, Constantinou replied, "Keeping my door open to anybody who wants to walk in and have a little talk. Learning from the students-their enthusiasm, their bravery, their sense of adventure, and being a part of it." Quite fitting at a college whose creed is "the adventure of a lifetime and a lifetime of adventure." 